\title{
Laboratory and instrumental parameters of patients with ischemic heart disease in dependence of gallbladder condition: correlational analysis
}

\author{
L. M. Strilchuk, I. B. Zhakun, Z. M. Kit, 0. O. Sorokopud, M. O. Kondratyuk \\ Danylo Halytsky Lviv National Medical University, Ukraine
}

Key words:

gallbladder coronary vessels, prothrombin time, alanin transaminase, statistics nonparametric.

Zaporozhye medical journal 2017; 19 (6), 748-751

DOl:

10.14739/2310-1210 2017.6.114707

E-mail:

larysa.stril4uk@ukr.net
The correlations of right coronary artery (RCA) diameter with gallbladder (GB) width and GB distension with the development of coronary arteries anomalies have already been described. Accordingly, the GB disorders are accompanied by structural and functional heart changes, but its exact criteria have not yet been established. Therefore, the substantiation of the prognostic role of GB distension as a risk factor for the coronary arteries anomalies development determined the usefulness of our study.

The aim of this study was to establish correlations of GB condition with clinical, laboratory and instrumental parameters in patients with ischemic heart disease (IHD).

Materials and methods. We analyzed 35 clinical, laboratory and instrumental parameters of 98 patients with verified IHD (40\% - acute myocardial infarction, $60 \%$ - unstable angina pectoris; $79 \%$ males and $21 \%$ females; mean age $-61.7 \pm 1.6$ years). These patients were divided into groups depending on $\mathrm{GB}$ condition (intact $\mathrm{GB}, \mathrm{n}=29$; sludge and cholesterosis, $n=13$; bend GB body, $n=13$; GB neck deformations and cholecystitis, $n=27$; cholelithiasis, $n=11$; cholecystectomy in anamnesis, $n=5$ ). Obtained data were analyzed with the help of correlation analysis (correlations of quantitative parameters - by Pearson's method and correlations of qualitative parameters - by Spearman's method). We took into account only significant correlations $(P<0.05)$. Ranking of $G B$ condition was held on the background of $G B$ disorders' pathogenesis: changes usually start from sludge and cholesterosis, which in case of various GB deformations together with bile flow difficulties and impaired GB motility lead to cholelithiasis. Complications of cholelithiasis can lead to cholecystectomy, which was rated the worst GB condition.

Results. The GB condition significantly correlated with RCA affection grade, alanine aminotransferase (ALT) activity and prothrombin time: worsening of GB condition was accompanied by increase of RCA stenosis grade on the background of decrease in prothrombin time (which shows tendency to hypercoagulability and thrombi formation) and absence of hepatocytes cytolysis. Correlations of RCA stenosis grade depended on GB conditions including metabolic, inflammatory and haemostatic parameters, size and blood supply of left atrium. Prothrombin time increasing was associated with left ventricle hypertrophy, hyperkaliemia, diastolic dysfunction and higher grade of RCA affection. ALT activity was proportional to ejection fraction together with general fibrinogen in case of GB sludge and to fasting glucose level in case of bent GB body.

Conclusions. Established reliable correlations of both type and degree of GB damage with RCA stenosis grade and other clinical, laboratory and instrumental parameters (prothrombin time, fibrinogen and ALT levels, hypertrophy and diastolic dysfunction of the left ventricle etc.) are associated with a tendency to hypercoagulability and thrombi formation, hyperkaliemia, and define both morphological and functional interrelations of GB disorders with coronary arteries anomalies. Thus, monitoring of these parameters has a significant prognostic value in the clinical practice and must influence the choice of appropriate therapeutic tactics.

\section{Ключові слова:}

жовчний міхур, коронарна артерія, протромбіновий час, аланінамінотрансфераза, кореляційний аналіз.

Запорізький медичний журнал. - 2017. T. 19, № 6(105). C. $748-751$

\section{Стан жовчного міхура та лабораторно-інструментальні параметри хворих на ішемічну хворобу серця: кореляційний аналіз}

\section{А. М. Стрільчук, І. Б. Жакун, З. М. Кіт, О. О. Сорокопуд, М. О. Кондратюк}

Наявність кореляційних зв'язків діаметра правої коронарної артерії (ПКА) з шириною жовчного міхура (ЖП) і біліарних шляхів $€$ відомим фрактом, але натепер не визначені їхні чіткі критерії. Тому обґрунтування прогностичної ролі розтягування жовчного міхура як фактора ризику розвитку аномалій коронарних артерій зумовило доцільність нашого дослідження.

Мета роботи - вивчення кореляцій стану ЖМ із клінічними, лабораторними та інструментально-діагностичними показниками у хворих на ішемічну хворобу серця (IXC).

Матеріали та методи. Проаналізували 35 клініко-лабораторних та інструментально-діагностичних показників 98 пацієнтів із верифікованою IXC (40 \% - гострий інфаркт міокарда, 60 \% - нестабільна стенокардія; 79 \% чоловіків і 21 \% жінок; середній вік - 61,7 \pm 1,6 року), яких поділено на групи залежно від стану ЖМ: інтактний (29); сладж і холестероз (13); перегини тіла (13); деформації шийки та холецистит (27); холелітіаз (11); холецистектомія в анамнезі (5), за допомогою кореляційного аналізу. Ранжування стану ЖМ здійснено на підставі того, що зміни починаються зі сладжу та холестерозу, що за умов деформацій тіла та шийки ЖМ з утрудненням відтоку жовчі та скоротливості, призводять до холелітіазу, ускладнення якого є показанням до холецистектомії. Кореляції кількісних ознак визначені за методом Пірсона, а якісних ознак - за непараметричним ранговим аналізом Спірмена, до уваги брали тільки істотні зв'язки $(p<0,05)$.

Результати. Встановили: з поглибленням уражень ЖМ зростав ступінь стенозу ПКА, що супроводжувалося зменшенням протромбінового часу (тенденція до гіперкоагуляції та тромбоутворення) за відсутності синдрому цитолізу гепатоцитів. Кореляції ступеня стенозу ПКА залежали від стану ЖМ і включали метаболічні, запальні, гемостазіологічні параметри, розмір і кровопостачання лівого передсердя (за ступенем оклюзії ообвідної артерії). Здовження протромбінового часу асоціювалося з гіпертрофрією лівого шлуночка, гіперкаліємією, діастолічною дисфункцією лівого шлуночка та ступенем ураження ПКА. Активність аланінамінотрансферази виявилась пропорційною фрракції викиду та загальному фібриногену за умов сладжу ЖМ і вмісту глюкози крові натще за умов перегину тіла ЖМ. 
Висновки. Встановлені вірогідні кореляції типу та ступеня ураження ЖМ зі стенозом ПКА та іншими клініко-лабораторними, інструментально-діагностичними показниками (протромбіновий час, вміст фібриногену, вміст АЛТ, гіпертрофія, діастолічна дисфункція лівого шлуночка тощо) асоціюються з тенденцією до гіперкоагуляції та тромбоутворення, гіперкаліємією та визначають як морфологічний, так і функціональний тісний зв'язок ураження ЖМ з аномаліями коронарних артерій. Тому моніторинг вказаних параметрів має велике прогностичне значення у клінічній практиці та виборі відповідної терапевтичної тактики.

\section{Состояние желчного пузыря и лабораторно-инструментальные параметры больных ишемической болезнью сердца: корреляционный анализ}

\section{А. Н. Стрильчук, И. Б. Жакун, З. М. Кит, Е. А. СорокопуА, М. А. Кондратюк}

Наличие корреляционных связей диаметра правой коронарной артерии (ПКА) с шириной желчного пузыря (ЖП) и билиарных путей является известным фактом, однако до сих пор не определены их чёткие критерии. Поэтому обоснование прогностической роли растяжения желчного пузыря как фактора риска развития аномалий коронарных артерий обусловило целесообразность нашего исследования.

Цель работы - изучение корреляций состояния ЖП с клиническими, лабораторными и инструментально-диагностическими показателями у больных ишемической болезнью сердца (ИБС).

Материалы и методы. Проанализировали 35 клинико-лабораторных и инструментально-диагностических показателей 98 пациентов с верифицированной ИБС (40 \% - острый инфраркт миокарда, 60 \% - нестабильная стенокардия; 79 \% мужчин и

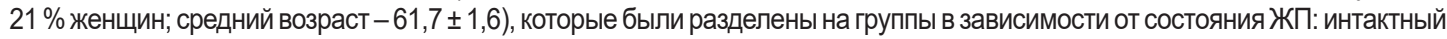
(29); сладж и холестероз (13); перегибы тела (13); деформации шейки и холецистит (27); холелитиаз (11); холецистэктомия в анамнезе (5), с помощью корреляционного анализа. Корреляции количественных параметров определены по методу Пирсона, качественных - с помощью непараметрического рангового анализа Спирмена, во внимание брались только существенные связи $(p<0,05)$. Ранжирование состояния ЖП проведено на основании того, что изменения начинаются со сладжа и холестероза, которые в условиях деформаций тела и шейки ЖП с затруднением оттока желчи и снижением сократительности ведут к холелитиазу, осложнения которого являются показанием к холецистэктомии.

Результаты. Нами установлено: с углублением поражений желчного пузыря возрастала степень стеноза ПКА, что сопровождалось уменьшением протромбинового времени (тенденция к гиперкоагуляции и тромбообразованию) при отсутствии синдрома цитолиза гепатоцитов. Корреляции степени стеноза ПКА зависели от состояния ЖП и включали метаболические, воспалительные, гемостазиологические параметры, размер и кровоснабжение левого предсердия (по степени окклюзии огибающей артерии). Удлинение протромбинового времени ассоциировалось с гипертрофией и диастолической дисфункцией левого желудочка, степенью поражения ПКА и гиперкалиемией. Активность аланинаминотрансферазы была пропорциональна фракции выброса и общему фибриногену при сладже ЖП, а также глюкозе крови натощак при перегибе тела ЖП.

Выводы. Установленные нами достоверные корреляции типа и степени поражения ЖП со стенозом ПКА и другими клинико-лабораторными, инструментально-диагностическими показателями (протромбиновое время, содержание фибриногена и АЛТ, гипертрофия, диастолическая дисффунция левого желудочка и другие) ассоциируются с тенденцией к гиперкоагуляции и тромбообразованию, гиперкалиемией и определяют как морфологическую, так и функциональную тесную связь поражения ЖП с аномалиями коронарных артерий. Поэтому мониторинг указанных параметров имеет большое прогностическое значение в клинической практике и выборе соответствующей терапевтической тактики.

\section{Introduction}

The fact that gallbladder (GB) disorders are accompanied by structural and functional heart changes (namely, cholecystocardial syndrome) has been known since long ago, but its exact criteria have not yet been established. Literature data on this topic are also scarce [1]. There is a description of right coronary artery (RCA) diameter correlation with GB width [2] and biliary tracts condition [3]. Some authors state that GB distension has a prognostic role in development of coronary arteries anomalies [4]. Absence of unified data determined the relevance and usefulness of our research.

Our aim was to establish correlations of GB condition with clinical, laboratory and instrumental parameters in patients with verified ischemic heart disease (IHD).

\section{Materials and methods}

We analyzed 98 patients preoperational examination results with clinically and instrumentally (including coronarography) verified diagnosis of $\mathrm{HD}$, who were planned to undergo coronary artery bypass graft surgery (CBG) (40\% - acute myocardial infarction, $60 \%$ - unstable angina pectoris; $79 \%$ males and $21 \%$ females; mean age $61.7 \pm 1.6$ years). These patients were divided into groups depending on GB condition (intact $\mathrm{GB}, \mathrm{n}=29$; sludge and cholesterosis, $n=13$; bent GB body, $n=13$; GB neck deformations and cholecystitis, $n=27$; cholelithiasis, $n=11$; cholecystectomy in anamnesis, $n=5$ ). Diagnostics and treatment were held according to Ministry of Health Decrees № 436 dated by 03. 07. 2006 and № 816 dated by 23.11. 2011 using standard methods. Digital data was processed with the help of Statistica 6.0 software (Statsoft, USA). Correlation analysis of 35 clinical, laboratory and instrumental parameters was carried out with the help of Pearson's method (quantitative parameters) and Spearmen's method (qualitative parameters). We took into account only significant correlations $(P<0.05)$. Ranking of $G B$ condition was held on the background of GB disorders' pathogenesis: changes usually start from sludge and cholesterosis, which in case of GB body and neck deformations together with bile flow difficulties and impaired GB motility lead to cholelithiasis. Complications of cholelithiasis can lead to cholecystectomy, which was rated as the worst GB condition.
Ключевые слова: желчный пузырь, коронарная артерия, протромбиновое время, аланинаминотрансфераза, корреляционный анализ.

\section{Запорожский} медицинский журнал. - 2017. T. 19, № 6(105). C. $748-751$ 


\section{Results and discussion}

According to carried out correlation analysis, GB condition directly correlated with RCA stenosis grade $(r=0.27$, $P<0.05)$, inversely - with alanine aminotransferase (ALT) activity $(r=-0.29, P<0.05)$ and prothrombin time $(r=-0.26$, $P<0.05)$. Direct association of GB condition with RCA stenosis grade not just proves previously described correlation between RCA and GB width [2,3], but also shows that this correlation it is both morphological and functional. This fact is crucial for clinical usage, because it means that GB disorders progression is parallel to RCA occlusion grade.

Taking into account the importance of this finding, we separately analyzed significant correlations of RCA stenosis grade in case of different GB condition: intact, sludge and cholesterosis, bent GB body, GB neck deformations and cholecystitis, cholelithiasis, cholecystectomy in anamnesis. It has been established in patients with intact GB RCA affection grade was directly proportional to affection of circumflex coronary artery $(r=0.63, P<0.05)$, whose atrial and ventricular branches provide blood supply of $20 \%$ of myocardium; left atrium size $(r=0.59, P<0.05)$, increase of which is a sign of diastolic dysfunction; and hematocrit $(r=0.64, P<0.05)$. The last correlation indicates that blood viscosity increasing goes parallel to RCA stenosis. In case of sludge and GB cholesterosis RCA stenosis grade correlated only with urea concentration $(r=-0.79, P<0.05)$. In patients with bent GB body RCA affection did not correlate to any studied parameters. In contrast to that, in group with GB neck deformations, which can be considered signs of chronic cholecystitis in the past, RCA stenosis grade significantly associated with coagulation and inflammation parameters - prothrombin index $(r=0.44, P<0.05)$ and general fibrinogen level $(r=-0.42, P<0.05)$. In case of GB cholelithiasis grade of RCA stenosis was inversely proportional to $\beta$-lipoproteids level $(r=-0.73, P<0.05)$ and serum urea concentration $(r=-0.82, P<0.05)$. In patients with $\mathrm{GB}$ removed because of cholelithiasis $\mathrm{RCA}$ affection grade directly correlated to general cholesterol level $(r=0.96$, $P<0.05)$ and inversely - to prothrombin time $(r=-0.98$, $P<0.05)$ and hematocrit $(r=-0.97, P<0.05)$.

The revealed inverse correlation of GB condition with prothrombin time must also be considered very important for clinical practice. This association could be the sign of parallel progression of GB disorders and hypercoagulability because of all components of external coagulation mechanism activation. That is why patients with major GB changes (cholelithiasis, condition after cholecystectomy, GB neck deformations and chronic cholecystitis) require active antithrombotic therapy.

We also analyzed significant correlations of prothrombin time with included clinical, laboratory and instrumental parameters depending on GB condition. Needless to say that prothrombin time had the direct correlation with prothrombin index in all groups, but other tendencies were different. In case of intact GB prothrombin time was directly proportional to right ventricle size $(r=0.48, P<0.05)$ and thickness of left ventricle posterior wall $(r=0.50, P<0.05)$; in patients with sludge and cholelithiasis there were not any significant correlations; in case of bent GB body we revealed correlations with thickness of left ventricle posterior wall $(r=-0.56, P<0.05)$ and potassium level $(r=-0.97$, $P<0.05)$; in case of $G B$ neck deformations - with left atrium size $(r=-0.45, P<0.05)$. In patients after cholecystecto- my prothrombin time correlated with RCA affection grade $(r=-0.98, P<0.05)$ and peripheral blood hemoglobin level $(r=0.91, P<0.05)$. Thus, development of hypercoagulability as a result of external coagulation mechanism activation depends on GB condition. Such hypercoagulability is associated with left ventricle hypertrophy in case of bent GB body, with hyperkaliemia and diastolic dysfunction in case of GB neck deformations and with RCA affection grade in patients after cholecystectomy. In patients with intact GB hypercoagulability is not accompanied by right ventricle dilatation and left ventricle hypertrophy.

It is quite interesting that, according to our results, progress of GB affection is not associated with increase of liver-specific transaminase - ALT (inverse correlation), meaning that GB changes develop autonomously. In general, correlations of ALT also were dependent on GB condition, but there were significantly less of them. Apart from significant associations with activity of aspartate aminotransferase (AST), which were noticed in all groups, we revealed quite strong bonds of ALT and ejection fraction $(r=0.60, P<0.05)$ and general fibrinogen level $(r=0.72, P<0.05)$ in case of sludge and with fasting glucose concentration $(r=-0.65$, $P<0.05$ ) in case of bent GB body. Thus, hepatic cytolysis is not an obligatory accompaniment of GB disorders, but progress of $\mathrm{GB}$ affection correlates with decrease of left ventricle ejection fraction together with activation of inflammation in case of sludge and with impaired glucose tolerance in case of bent GB body. Investigation of transaminases prognostic role in 2417 patients after percutaneous coronary intervention because of myocardial infarction showed that increase of ALT level correlated with stenosis of anterior interventricular artery and RCA. Increase of ALT concentration in these patients was associated with increased mortality immediately after intervention and in the remote period [5].

\section{Conclusions}

1. GB condition significantly correlated with RCA affection grade, ALT activity and prothrombin time: worsening of GB condition was accompanied by increased of RCA stenosis grade on the background of prothrombin time shortening (which shows tendency to hypercoagulability and thrombi formation) and absence of hepatocytes cytolysis. Correlations of RCA stenosis grade were dependent on GB conditions. They included metabolic, inflammatory and haemostatic parameters, size and blood supply of left atrium.

2. Prothrombin time prolongation was associated with left ventricle hypertrophy, hyperkaliemia, diastolic dysfunction and higher grade of RCA affection.

3. ALT activity was proportional to ejection fraction together with general fibrinogen in case of sludge and to fasting glucose level in case of bent GB body.

The further investigation of GB condition dynamics and other clinical, laboratory and instrumental parameters together with coronary arteries pathology and the establishment of their parallel interrelations is a promising field of a future research.

\section{References}

[1] Gonzalez-Perez, A., \& Garcia Rodriguez, L. A. (2007) Gallbladder disease in the general population: association with cardiovascular morbidity and therapy. Pharmacoepidemiology and drug safety, 16(5), 524-531. doi: $10.1002 / p d s .1346$. 
[2] Corbitt, J. D. Jr., Levin, J. M., Walker, L. J. Jr., \& Haynes, C. D. (1970) Relationship between biliary tract distention and the blood flow in the aorta and right coronary and renal arteries. American journal of surgery, 120(1), 14-15.

[3] Kim, K. -W., Kim, H. Y., Chun, J. -K., Cha, B. H., Namgoong, M. K., Kwon, W., \& Lee, H. Y. (2010) Relationship between gallbladder distension and lipid profiles in Kawasaki disease. Korean circulation journal, 40(3), 137-140. doi: 10.4070/kcj.2010.40.3.137.

[4] Yi, D. Y., Kim, J. Y., Choi, E. Y., Choi, J. Y., \& Yang, H. Y. (2014) Hepatobiliary risk factors for clinical outcome of Kawasaki disease in children. BMC pediatrics, 14, 51. doi: 10.1186/1471-2431-14-51.

[5] Gao, M., Cheng, Y., Zheng, Y., Zhang, W., Wang, L., \& Ling Qin, L. (2017) Association of serum transaminases with short- and long-term outcomes in patients with ST-elevation myocardial infarction undergoing primary percutaneous coronary intervention. BMC cardiovascular disorders, 17(1), 43. doi: 10.1186/s12872-017-0485-6.

\section{Information about authors:}

Strilchuk L. M., MD, PhD, Assistant, Department of Therapy No. 1 and Medical Diagnostic FPGE, Danylo Halytsky Lviv National Medical University, Ukraine.

Zhakun I. B., MD, PhD, Associate Professor, Department of Internal Medicine No. 2, Danylo Halytsky Lviv National Medical University, Ukraine.

Kit Z. M., MD, PhD, Associate Professor, Department of Family Medicine, Danylo Halytsky Lviv National Medical University, Ukraine. Sorokopud 0. 0., MD, PhD, Associate Professor, Department of Internal Medicine No. 2, Danylo Halytsky Lviv National Medical University, Ukraine.

Kondratyuk M. O., MD, PhD, Associate Professor, Department of Internal Medicine No. 2, Danylo Halytsky Lviv National Medical University, Ukraine.

\section{Відомості про авторів:}

Стрільчук ^. М., канА. меА. наук, асистент каф. терапії № 1 та медичної Аіагностики ФПАО, Аьвівський національний медичний університет імені Аанила Галицького, Україна. Жакун І. Б., канА. меА. наук, Аоцент каф. внутрішньої меАицини № 2, ^ьвівський національний меАичний університет імені Аанияа Галицького, Україна.

Кіт 3. М., канд. меА. наук, Аоцент каф. сімейної медицини, ^ьвівський національний медичний університет імені Аанила Галицького, Україна.

Сорокопуд О. О., канА. меА. наук, Аоцент каф. внутрішньої медицини № 2, Аьвівський національний меАичний університет імені Аанила Галицького, Україна.

Кондратюк М. О., канА. меА. наук, Аоцент каф. внутрішньої медицини № 2, ^ьвівський національний меАичний університет імені Аанияа Галицького, Україна.

\section{Сведения об авторах:}

Стрильчук $\Lambda$. Н., канА. меА. наук, ассистент каф. терапии № 1 и меАицинской Аиагностики ФПАО, Аьвовский национальный медицинский университет имени Аанила Галицкого, Украина. Жакун И. Б., канА. меА. наук, Аоцент каф. внутренней медицины № 2, ^ьвовский национальный медицинский университет имени Аанила Галицкого, Украина.

Кит 3. М., канА. меА. наук, Аоцент каф. семейной медицины, ^ьвовский национальный медицинский университет имени Аанила Галицкого, Украина.

Сорокопуд Е. А., канА. меА. наук, Аоцент каф. внутренней меАицины № 2, Аьвовский национальный меАицинский университет имени Аанила Галицкого, Украина. Кондратюк М. О., канА. меА. наук, Аоцент каф. внутренней медицины № 2 ,

^ьвовский национальный медицинский университет имени Аанила Галицкого, Украина.

Конфмікт інтересів: віАсутній

Conflicts of Interest: authors have no conflict of interest to declare. 